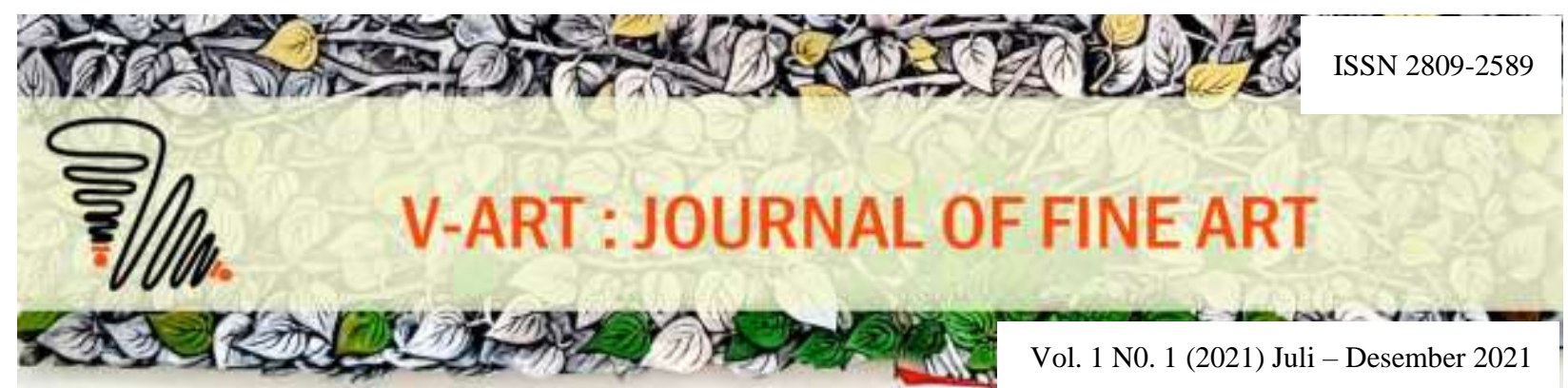

\title{
Monumen Perjuangan Masyarakat Cupak Ditinjau Dari Segi Bentuk, Fungsi Dan Tata Letak
}

\author{
Dinda Fitria ${ }^{1}$, Maulid Hariri Gani ${ }^{2}$, dan Rica Rian ${ }^{3}$ \\ Prodi Seni Murni, Fakultas Seni Rupa dan Desain \\ Institut Seni Indonesia Padangpanjang \\ Jalan Bahder Johan No. 35, Kelurahan Guguk Malintang, Padangpanjang, 27128 \\ Provinsi Sumatera Barat, Indonesia \\ Email:dhindafitria7429@gmail.com, maulidharirigani@gmail.com,dan ricarian341@gmail.com
}

\begin{abstract}
Abstrak
Penelitian ini membahas tentang Monumen Perjuangan Masyarakat Cupak di Kabupaten Solok ditinjau dari segi bentuk, fungsi dan tata letak. Selain itu dibahas sekilas tentang sejarah singkat dibalik pendirian monumen. Penelitian ini menggunakan pendekatan kualitatif yang meliputi observasi, wawancara, studi pustaka, serta penelitian dilakukan secara langsung ke lapangan yaitu ke daerah Cupak di Kabupaten Solok Sumatera Barat. Berdasarkan hasil dari penelitian yang dilakukan, diketahui bahwa pembangunan Monumen Perjuangan Masyarakat Cupak bertujuan untuk memperingati masa perjuangan masyarakat Cupak dalam melawan tentara Jepang, serta bentuk dari monumen merupakan visual 3 orang pejuang di antaranya patung terdiri dari figur yang berpakaian tentara Republik Indonesia, tentara Jepang dan pejuang masyarakat. Tata letak Monumen Perjuangan Masyarakat Cupak sangat erat kaitannya dengan fungsi dari monumen itu sendiri, monumen yang memiliki fungsi sosial dan fungsi fisik yaitu monumen yang jika diciptakan dan dilihat dalam skala publik, artinya dapat menjangkau masyarakat luas.
\end{abstract}

Kata Kunci: monumen perjuangan masyarakat Cupak, bentuk, fungsi, tata letak.

\begin{abstract}
This study discusses the Cupak Community Struggle Monument in Solok Regency in terms of form, function, and layout. In addition, we briefly discuss the brief history behind the monument's establishment. This study uses a qualitative approach which includes observations, interviews, literature studies, and research is carried out directly to the field, namely to the Cupak area in Solok Regency, West Sumatra. Based on the results of the research conducted, it is known that the construction of the Cupak Community Struggle Monument aims to commemorate the period of the Cupak people's struggle against the Japanese army, and the shape of the monument is a visual representation of 3 warriors including statues consisting of figures dressed in Indonesian soldiers, Japanese soldiers, and community warrior. The layout of the Cupak Community Struggle Monument is closely related to the function of the monument itself, a monument that has a social function and a physical function, namely a monument which, if created and viewed on a public scale, means that it can reach the wider community.
\end{abstract}

Keywords: Cupak community struggle monument, form, function, layout.

\section{PENDAHULUAN}

Monumen adalah bangunan dan tempat yang mempunyai sejarah penting. Monumen-monumen perjuangan yang dibangun di sebuah daerah adalah sebuah karya seni monumental yang menjadi pengingat atau penanda salah satu peristiwa atau sejarah perjuangan yang pernah terjadi di daerah tersebut. Sekaitan dengan hal tersebut, penulis ingin melihat bagaimana monumen-monumen yang ada tersebut menyampaikan makna atau arti tersendiri bagi masyarakat pemiliknya. Monumen merupakan bentuk hasil dari seni patung. Monumen sebagai bangunan dan tempat yang mempunyai nilai sejarah, diciptakan dengan maksud mengabadikan kenangan terhadap seseorang atau peristiwa dalam skala besar, dan kesederhanaan sering terlihat sebagai faktor yang menciptakan keagungan. Keagungan tersebut terlihat sebagai atribut monumen, begitu pula dengan idealis bentuk, sikap, harmoni dalam bentuk keselarasan antara massa dan gerak. Monumen memiliki struktur 
bentuk yang mempunyai tujuan utama sebagai peringatan akan suatu kejadian (Mikke Susanto, 2002). Sifat monumental merupakan bentuk yang memenuhi persyaratan keindahan dari seluruh benda seni yang memperlihatkan sifat agung dan megah tersebut.

Sebagaimana Monumen-Monumen yang tersebar di wilayah Kota dan Kabupaten Solok dengan berbagai bentuk, struktur, makna, sejarah dan lokasi penempatannya, Monumen Perjuangan Masyarakat Cupak di Kabupaten Solok tentunya juga memiliki latar belakang dari perwujudan bentuk, struktur, makna, dan lokasi penempatannya. Hal tersebut yang menjadi pembahasan kajian monumen ini, begitu juga dengan dampak dari perjuangan bagi kemerdekaan bangsa hingga dibangun Monumen Perjuangan di daerah tersebut.

Pada masa perjuangan banyak daerah lain yang terletak di Kabupaten Solok yang juga merasakan pahitnya era penjajahan saat itu, dari hal tersebut muncul asumsi baru apakah hanya masyarakat Cupak yang ikut berjuang, ataukah perjuangan saat itu berpusat di daerah Cupak, hingga berkemungkinan kontribusi Masyarakat Cupak lebih tinggi dibandingkan dengan masyarakat di daerah lain.

\section{KAJIAN TEORI}

\section{Monumen}

Monumen harus mencangkup nilai bentuk dan nilai isi. Nilai bentuk adalah nilai yang terkandung pada gerak aspek perwujudan visual yang menyangkut masalah keharmonisan bentuk. Sedangkan nilai isi, nilai yang terkandung pada segala aspek dan dapat ditafsirkan di balik perwujudan sebagai bentuk visual yang disampaikan. Bentuk yaitu "sebuah benda seni harus memiliki wujud agar dapat diterima, dilihat, didengar oleh orang lain baik benda seni yang bersifat fisik dan non fisik" (Sumardjo, 2000). "Menurut pakar filsafat sejati dalam sandiwara Moliere The Forced Marriage, bentuk adalah "manifestasi fisik luar dari suatu objek yang hidup" tetapi bidang adalah manifestasi dari suatu objek yang mati" (Fieldman, 1991: 186-187).

\section{Relief}

Skulpture relief atau rivilio berasal dari bahasa Italia yang berarti peninggian, dalam arti yang kedudukannya lebih tinggi dari pada latar belakangnya (Sahman, 1993). Relief berasal dari bahasa Latin relevare yang artinya pengangkatan atau meninggikan. Dalam kajian arkeologi, relief merupakan bentuk seni rupa pahat yang berada pada dinding bangunan suci yang membantu proses peribadatan dan membentuk nilai kesakralan. Di dalam penceritaan, relief mempunyai dua gaya bercerita yang berbeda. Relief mempunyai dua macam, yaitu relief hias dan relief cerita, relief hias adalah berbagai bentuk ukiran berupa ornamen yang tidak mengandung cerita, misalnya sulur daun, bunga dan lain-lain. Relief cerita adalah relief yang memaparkan suatu cerita dalam bentuk gambar pahatan, misalnya relief Lalitavistara Candi Borobudur atau relief Candi Siva Prambanan.

Berhubungan dengan bentuk juga dibahas tentang unsur-unsur seni rupa, di mana unsur seni rupa yaitu titik, garis, bidang, tekstur, warna, ruang, gelap terang dan gerak, untuk menggali tentang unsur-unsur seni rupa digunakan teori bentuk. Bentuk yaitu: "sebuah benda seni harus memiliki wujud agar dapat diterima, dilihat, didengar oleh orang lain baik benda seni yang bersifat fisik dan non fisik". Bentuk memiliki unsurunsur yang tergabung dalam satu kesatuan organisasi rupa yang meliputi: titik, garis, bidang, warna, tekstur, dan sebagainya, rupa bentuk dari suatu benda yang berada di dalam batas-batasnya sendiri (Sumardjo, 2000).

\section{Unsur-unsur seni rupa}

a. Garis

Garis merupakan sisi sebuah bidang. Kehadiran garis dalam seni rupa tidak sejatinya sebagai garis semata tetapi terkadang sebagai simbol emosi yang diungkapkan lewat garis, atau lebih tepat disebut sebagai goresan (Wucius Wong, 1989).

\section{b. Shape}

Shape berarti bentuk dalam (external form) atau kontur (pinggiran) dari objek atau daerah (Susanto, 2011). Shape (bidang) ada dua pengertian (a) Shape mempunyai wujud alam (figur) dan (b) Shape yang tidak mempunyai wujud alam (non figur). Keduanya terjadi berdasarkan kemampuan seniman mengolah objek melalui: stilisasi, distorsi, transformasi dan disformasi (Darsono, 2007).

\section{c. Tekstur}

Tekstur atau barik merupakan peristiwa khas tentang kecengkahan barik yaitu licin/ kasap, halus/ kasar, rata/ tak rata, kusam/ mengkilap, dan seterusnya (Wucius Wong, 1989). Tekstur adalah unsur rupa yang menunjukkan rasa permukaan bahan atau bidang pada perwajahan bentuk pada karya secara nyata atau semu.

d. Warna

Warna didefinisikan sebagai getaran atau gelombang yang diterima indera penglihatan manusia yang 
berasal dari pancaran cahaya melalui sebuah benda (Susanto, 20011:433). Demikian eratnya hubungan warna dengan kehidupan manusia, maka warna mempunyai peranan yang sangat penting, yaitu: warna sebagai warna, warna sebagai representasi alam, warna sebagai lambang/simbol, dan warna sebagai simbol ekspresi. (Dharsono, 2007:39).

\section{e. Ruang}

Ruang adalah bidang yang memiliki batas atau limit. Ruang adalah rongga yang tidak terbatas tempat segala yang ada. Ruang dalam unsur rupa merupakan wujud trimatra yang mempunyai panjang, lebar, tinggi dan volume.

\section{Prinsip Desain dalam Seni Patung \\ a. Kesatuan (Unity)}

Kesatuan adalah menyatunya unsur-unsur rupa setelah disusun dan menimbulkan arti serta makna baru susunan tersebut. Kesatuan tersebut merupakan organisasi unsur rupa dengan menerapkan prinsip penyusunan, prinsip yang menunjang bagaimana unsur-unsur dalam seni rupa saling berpadu satu sama lain sehingga saling menunjang dalam membangun sebuah komposisi yang menarik dan indah.

\section{b. Keseimbangan (Balance)}

Keseimbangan menyatukan kekuatan antar unsur rupa sehingga adalah tidak menimbulkan kesan berat sebelah. Keseimbangan dalam seni rupa merupakan persesuaian materi-materi dari ukuran berat dan memberi tekanan pada stabilitas komposisi karya seni. Keberadaan ukuran, wujud, warna, tekstur dan semua unsur menjadi perhatian dan pertimbangan dalam penyusunan bentuk.

\section{c. Proporsi}

Proporsi adalah perbandingan unsur-unsur satu dengan lainnya tentang ukuran kualitas dan tingkatan. Proporsi dapat dipakai sebagai salah satu pertimbangan untuk mengukur dan menilai keindahan artistik karya seni. Proporsi tidak terpisahkan dan berhubungan dengan keseimbangan, harmoni dan kesatuan.

\section{Fungsi Monumen}

Menciptakan bentuk harus sesuai dengan fungsi. Antara bentuk dan fungsi harus terjalin hubungan yang tidak terpisahkan. Fungsi ialah: kegunaan suatu hal, fungsi adalah sesuatu yang mampu menjalankan peran utamanya. Seni berlangsung untuk memuaskan: 1) kebutuhan-kebutuhan individual kita tentang ekspresi pribadi (fungsi personal), 2) kebutuhan sosial kita perayaan dan komunikasi (fungsi sosial) serta, 3) kehidupan kebutuhan fisik kita mengenai barang- barang dan bangunan-bangunan yang bermanfaat, (fungsi fisik) (Gustami, 1990).

\section{Tata Letak}

Tata letak menurut istilah merupakan usaha untuk menyusun, menata, atau memadukan elemen-elemen atau unsur-unsur komunikasi grafis (teks, gambar, tabel dan lain-lain) menjadikan komunikasi visual yang komunikatif, estetik dan menarik. selain itu, perencanaan tata letak didefinisikan sebagai tempat pengaturan sumber daya fisik yang digunakan untuk membuat produk.

\section{METODE PENELITIAN}

Jenis penelitian yang digunakan adalah penelitian kualitatif. Penelitian kualitatif adalah penelitian yang menghasilkan data deskriptif berupa kata-kata tertulis atau lisan dari orang-orang dan prilaku yang dapat diamati" (Lexy J. Moleong, 2004). Penelitian ini akan memberikan dan mendeskripsikan semua fakta yang terjadi saat penelitian berlangsung yaitu mengenai bentuk, fungsi, dan tata letak Monumen Perjuangan Masyarakat Cupak di Kabupaten Solok.

Jenis data yang digunakan dalam penelitian ini adalah data primer dan sekunder. Data primer berupa hasil survei kelapangan melalui foto, rekaman hasil wawancara dan data tertulis. Sedangkan data sekunder diambil dari perpustakaan merupakan sumber tertulis mengenai teori-teori yang berhubungan dengan penelitian. Sumber tertulis tersebut dapat berupa buku, artikel, katalog, dan naskah lainnya.

Studi kepustakaan merupakan teknik pengumpulan data dengan menghimpun dan menganalisis dokumendokumen, baik secara tertulis, gambar maupun elektronik yang dilakukan oleh peneliti. Dilihat dari segi sumber data, bahan tambahan yang berasal dari sumber tertulis dapat dibagi atas sumber buku dan majalah ilmiah, sumber dari arsip, dokumen pribadi, dan dokumen resmi (Lexy J. Moleong, 2004). Selain studi pustaka, teknik pengumpulan data dilakukan melalui observasi. Observasi langsung dilakukan di lokasi didirikannya monumen, tepatnya di daerah Cupak Kabupaten Solok.

Untuk mendapatkan data yang akurat, peneliti juga melalukan wawancara. Peneliti melakukan wawancara langsung kepada pihak yang bersangkutan yaitu dengan Bapak Asnam Rasyid selaku ketua proyek. Wawancara juga dilakukan dengan Rajudin sebagai anggota tim proyek yang membuat rancangan/ desain 
monumen serta ikut dalam pengerjaan monumen dari awal sampai selesai. Wawancara juga dilakukan dengan pihak pemerintahan Kabupaten Solok, dalam hal ini peneliti melakukan sesi wawancara dengan Dinas Pariwisata Kabupaten Solok, yaitu dengan ibu Emi selaku kepala bidang pariwisata dan budaya yang berada di Kayu Aro Kabupaten Solok. Kemudian wawancara juga dilakukan dengan penduduk setempat sekitar lokasi monumen.

Teknik analisis data yaitu analisis deskriptif. Analisis data adalah upaya yang dilakukan dengan jalan bekerja dengan data, memilah-milahnya menjadi satuan yang dapat dikelola, menemukan apa yang penting dan apa yang dipelajari lalu memutuskan apa yang dapat diceritakan kepada orang lain (Lexy J. Moleong, 2004). Sehubungan dengan penjelasan di atas peneliti langsung turun ke lapangan guna untuk mencari data atau informasi

\section{HASIL DAN PEMBAHASAN}

\section{Sejarah Tentang Monumen Perjuangan Masyarakat Cupak}

Monumen Perjuangan Masyarakat Cupak dibuat berdasarkan sejarah perjuangan masyarakat Cupak setelah kemerdekaan. Masyarakat Cupak dijajah kembali oleh tentara Belanda hingga menewaskan banyak orang serta mengakibatkan daerah ini menjadi sangat kacau, tidak hanya masyarakat Cupak tetapi juga daerah-daerah lainnya di Kabupaten Solok, seperti Gantung Ciri, Guguak dan daerah kecil lainnya.

Cupak merupakan daerah yang paling lama dijajah oleh tentara Belanda yaitu lebih kurang 4 tahun lamanya (1945-1949). dengan terjadinya kekacauan di daerah Cupak dan sekitarnya, banyaknya peninggalan sejarah yang dibakar oleh tentara Belanda di antaranya Rumah Gadang yang merupakan mayoritas tempat tinggal masyarakat saat itu, tidak hanya di daerah Cupak daerah lainnya merasakan hal yang sama.

Monumen Perjuangan Masyarakat Cupak dibangun pada tahun 2002, untuk mengingat kembali sejarah perjuangan yang terjadi di daerah Cupak. Bupati Kabupaten Solok saat itu yaitu Gamawan Fauzi memanggil beberapa orang perupa untuk mengerjakan pembuatan patung Monumen Perjuangan Masyarakat Cupak, Yaitu: Asnam Rasyid yang saat itu bertugas sebagai tenaga ahli dan sekaligus sebagai Pimpinan proyek, Rajudin yang saat ini merupakan dosen pada Program Studi Seni Murni di Institut Seni Indonesia (ISI) Padangpanjang, saat pembuatan Monumen bertugas sebagai tenaga ahli dan pembuat desain/ rancangan monumen dan relief. Perupa lainnya adalah salah seorang Dosen UNRI (Universitas Riau) yaitu Zariul Antosa, yang saat itu bertugas sebagai tenaga ahli.

\section{Bentuk, Fungsi dan Tata Letak Monumen Perjuangan Masyarakat Cupak}

a. Bentuk Pada Monumen Perjuangan Masyarakat Cupak

Patung Monumen Perjuangan Masyarakat Cupak termasuk pada patung figur yang meniru bentuk secara alamiah. Misalnya: manusia, hewan atau tumbuhan, bentuk karya ini dibuat secara utuh sesuai dengan bentuk aslinya, dilihat dari bentuk patung yang menvisualisasikan bentuk manusia secara utuh.

Bentuk-bentuk yang ada pada Monumen Perjuangan Masyarakat Cupak ialah visualisasi 3 orang pejuang, pejuang pertama berpakaian tentara Indonesia dan menghadap ke arah kota Solok, satu orang pejuang sipil yang menggenggam bendera yang menghadap ke arah Padang, dan satu orang pejuang yang menggunakan seragam tentara Jepang mengarah ke pasar Cupak. Visualisasi tersebut dapat dilihat pada gambar berikut:

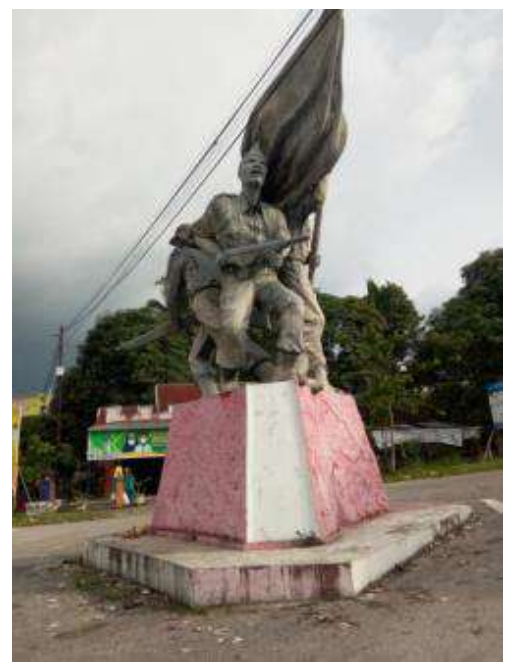

Gambar 1. Figur Tentara RI Menghadap ke Arah Kota Solok (Dhinda Fitria, 2020)

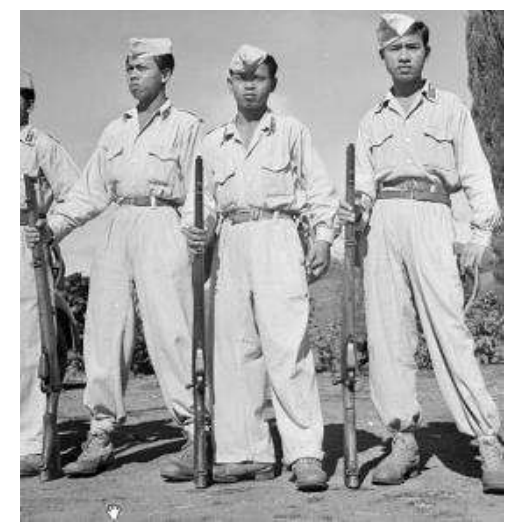

Gambar 2. Pakaian Tentara RI Pada Masa Perjuangan (Sumber: https://tinyurl.com/bd8bc373) 
Bentuk seragam Tentara yang divisualisasikan pada figur ini adalah adaptasi dari bentuk pakaian tentara Republik Indonesia pada masa penjajahan. Tentara yang terlihat sedang memegang senjata dengan gestur seperti sedang membidik sesuatu dilihat dari arah mata dan senapan yang menghadap ke arah yang sama, dengan satu tangan kanan memegang bagian ujung belakang senapan dan tangan kiri memegang bagian bawah senapan untuk siap melancarkan serangan. Hal ini didukung juga dengan posisi kaki yang merupakan posisi siaga posisi siaga dasar, di mana kaki kanan ke belakang, kaki kiri di depan lutut ditekuk, kaki kanan di belakang lutut diluruskan, kedua telapak kaki diluruskan ke depan.

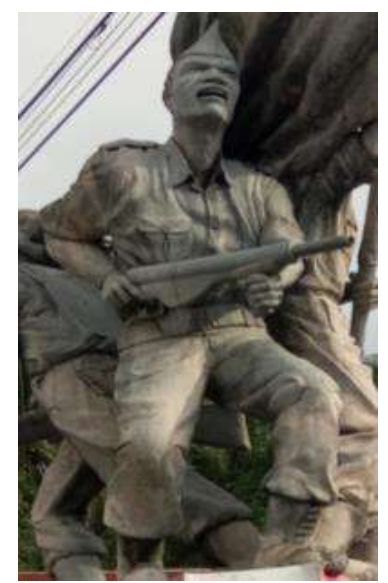

Gambar 3. Visualisasi Tentara RI Pada Monumen (Dhinda Fitria, 2020)

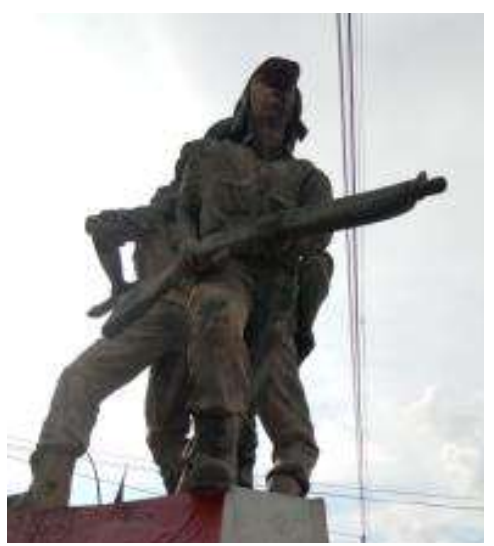

Gambar 4. Visualisasi Pejuang yang Menggunakan Seragan Tentara Jepang (Dhinda Fitria, 2020)

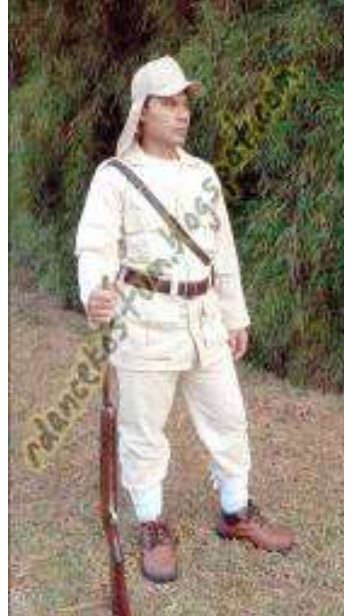

Gambar 5. Visualisasi Pejuang yang Menggunakan Seragan Tentara Jepang

(sumber: https://tinyurl.com/2p88863w)

Visualisasi bentuk pakaian figur yang kedua pada Monumen Perjuangan Masyarakat Cupak yaitu adaptasi dari pakaian seragam tentara Jepang. Jenis senjata yang jika yaitu type 99 Rifle Arisaka dengan berat $3,7 \mathrm{~kg}$. Posisi tangan kanan memegang bagian belakang tepatnya posisi di dekat penarik pelatuk ketika bersiap untuk menembakkan senjata dan jari telunjuk dikaitkan pada bagian pelatuk dalam posisi siaga, untuk menembakkan senjata dan tangan kiri memegang bagian depan senjata untuk menopang beban senjata dan agar lebih mudah untuk mengarahkan senjata ke target. Bagian kaki dengan posisi seperti akan melangkah ditandai dengan posisi kaki kanan yang ditekuk dan berada di depan sedangkan kaki kiri di belakang dalam keadaan lurus dengan telapak kaki yang lurus ke depan dan langkah yang besar.

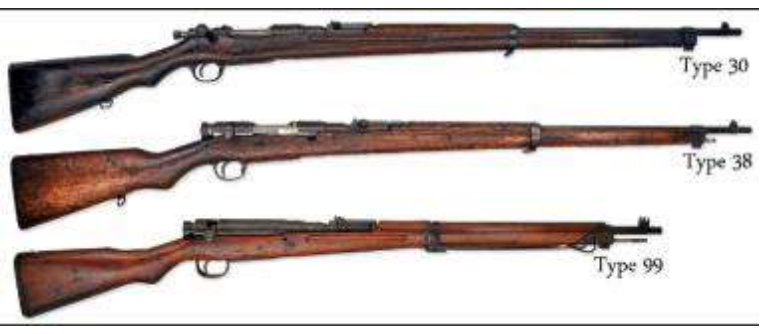

Gambar 6. Bentuk Senjata Arisaka (Sumber: https://tinyurl.com/2p8e6uh5) 


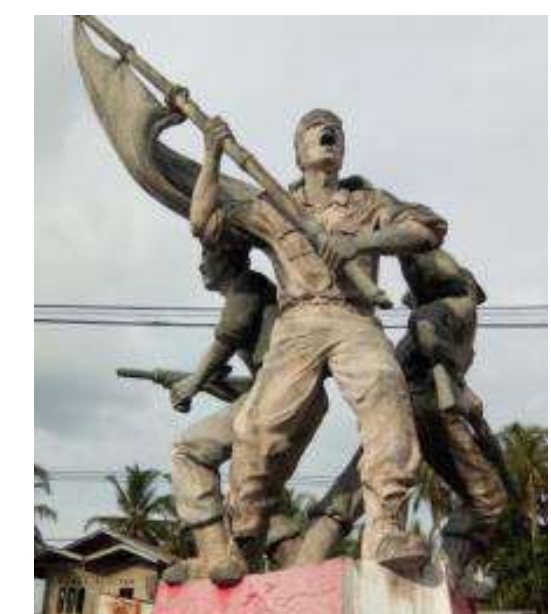

Gambar 7. Visualisasi Pejuang RI Berpakaian Sipil (Dhinda Fitria, 2020)

Visualisasi figur yang ketiga merupakan seorang pejuang dari kalangan sipil yang sedang memegang bendera dengan tiang dari bambu, tangan kiri berada di bagian ujung bawah bambu sebagai tumpuan atau untuk menopang berat, dan tangan kanan di bagian atas untuk mengayunkan saat mengibarkan bendera. Pejuang menggunakan peci dan baju yang berkerah, lengan baju digulung hingga di atas siku, bercelana panjang. Posisi badan yang seimbang dengan kaki kiri sedikit maju ke depan dan sedikit ditekuk dan kaki kanan berada di bagian belakang. Ekspresi seperti sedang berteriak.

Analisis Unsur-Unsur Rupa Pada Monumen Perjuangan Masyarakat Cupak

Garis yang terdapat pada Monumen Perjuangan Masyarakat Cupak di antaranya garis tegak yaitu garis yang terdapat pada bagian footstage, garis lurus berkesan tegak dan keras. Pada monumen garis tegak bermaksud untuk memberikan kesan tinggi dan kokoh. Garis lengkung terlihat pada bagian bendera, garis lengkung merupakan garis yang dominan terlihat. Garis lengkung dimaksudkan untuk menampilkan gerak yang dinamis pada monumen gerak yang bebas dan realis. Garis bergelombang terlihat di bagian gradasi baju figur, dimaksudkan untuk menampilkan gerak yang dinamis hingga patung terlihat hidup dan tidak kaku.

Tekstur yang ada pada Monumen Perjuangan Masyarakat Cupak yaitu tekstur kasar. Hal ini disebabkan karena bahan yang digunakan yaitu semen. Faktor cuaca tampaknya sedikit-sedikit telah merusak tekstur permukaan monumen. Hal ini mungkin pula disebabkan karena telah lama monumen tidak diberi cat yang berkualitas baik, sehingga dapat melindungi permukaan monumen dari cuaca.
Monumen Perjuangan Masyarakat Cupak pada pembuatan awalnya diberi warna abu-abu kebiruan, mirip seperti warna semen asli. Sehingga terlihat seperti tidak diberi cat. Cat yang digunakan adalah cat akrilik merk Dulux untuk eksterior. Seiring waktu berjalan masyarakat sekitar mewarnai bagian relief dan footstage monumen dengan warna merah pada bagian relief serta warna putih pada bagian pinggirnya. Terakhir warnanya tidak begitu menarik lagi, dan sudah terlihat sangat kusam.

Analisis Prinsip-Prinsip Rupa Pada Monumen Perjuangan Masyarakat Cupak

Pada Monumen Perjuangan Masyarakat Cupak kesatuan terbentuk dari garis, bidang, tekstur dan warna. Unsur-unsur ini terlihat saling menguatkan satu sama lain, membentuk sebuah karya seni yaitu Monumen Perjuangan Masyarakat Cupak.

Keseimbangan yang digunakan pada Monumen Perjuangan Masyarakat Cupak adalah keseimbangan asimetris. Dari berbagai arah dapat dilihat, bahwa monumen ini tidak ada yang sama antara kiri dan kanan maupun antara bagian bawah dan bagian atas, namun karya ini terlihat seimbang dengan baik.

Ukuran tinggi figur pada monumen diperkirakan 1:2 manusia laki-laki dewasa Indonesia, dengan ukuran ideal rata-rata $160 \mathrm{~cm}-175 \mathrm{~cm}$. Jadi dapat diperkirakan tinggi figur patung pada monumen ini berkisar antara $320 \mathrm{~cm}-350 \mathrm{~cm}$. Proporsi yang digunakan pada Monumen Perjuangan Masyarakat Cupak adalah proporsi ideal menggunakan modulus kepala, yaitu antara 7,5 sampai 8 kepala, sehingga figur terlihat anggun, atletis, megah dan kokoh.

\section{b. Fungsi Monumen Perjuangan Masyarakat Cupak}

Fungsi Monumen Perjuangan Masyarakat Cupak ini antara lain: (1) kebutuhan individual tentang ekspresi pribadi (fungsi personal). Fungsi ini terdapat pada individu seniman yang terlibat dalam pembuatan monumen ini. (2) kebutuhan sosial sebagai perayaan dan komunikasi. Fungsi ini termasuk di dalamnya sebagai pengingat momen sejarah yang pernah terjadi di daerah Cupak. Monumen ini membangkitkan kembali memori masyarakat akan peristiwa yang sangat bersejarah yang tidak akan mungkin mereka lupakan, dan memang harus selalu diingat kembali dan akan diceritakan kembali kepada generasi penerus bangsa. Ada nilai-nilai patriotisme yang mesti dipupuk dan selalu ditumbuhkembangkan kepada generasi muda. (3) kehidupan kebutuhan fisik mengenai barang-barang dan bangunan-bangunan yang bermanfaat. Fungsi ini termasuk di dalamnya adalah 
monumen sebagai tujuan destinasi wisata dan sebagai penanda jalan atau landmark daerah Cupak.

\section{c. Tata Letak Monumen Perjuangan Masyarakat Cupak}

Pembangunan Monumen Perjuangan Masyarakat Cupak sebagai lokasi bangunan monumen ditentukan oleh pihak Pembangunan Umum Pemerintah Kabupaten Solok yaitu di persimpangan tiga antara Kota Solok, jalan ke arah Padang dan pasar Cupak, Pemilihan lokasi ini disebabkan karena letaknya yang masih berada di daerah Cupak Kabupaten Solok karena di sana merupakan tempat terjadinya peristiwa perjuangan, dan persimpangan tiga tersebut dekat dengan khalayak umum, serta merupakan jalur yang selalu dilewati oleh pengendara karena merupakan jalan utama, dan luasnya yang cukup ideal untuk pembangunan monumen.

Tata letak Monumen Perjuangan Masyarakat Cupak sangat erat kaitannya dengan fungsi dari monumen itu sendiri, monumen yang memiliki fungsi sosial dan fungsi fisik yaitu monumen yang jika diciptakan dan dilihat dalam skala publik, artinya dapat menjangkau masyarakat luas. Seperti monumen yang ditempatkan di kawasan yang ramai atau di lingkungan tertentu, orang yang melaluinya akan menjadikan atau menandai sebagai peta atau tentang tempat, peristiwa, kejadian atau sebuah bentuk keindahan yang direspon oleh lingkungan komunitasnya.

Lokasi pendirian monumen dipilih sesuai dengan kondisi daerah sekitar yang strategis dan menjadi lokasi yang mudah di jangkau dan dilalui oleh khalayak umum. Lokasi pendirian monumen juga erat kaitannya dengan bentuk monumen saat ini, bentuk monumen yang menyesuaikan dengan kondisi jalan yang berada tepat di persimpangan tiga, hingga footstage dan patung yang berada di atasnya berbentuk segi tiga dan berjumlah tiga figur.

Penempatan monumen juga memberi dampak positif bagi lalu lintas sekitar persimpangan tiga tersebut, dengan berdirinya Monumen Perjuangan Masyarakat Cupak di sana lalu lintas menjadi lebih teratur dan area sekitar monumen juga dimanfaatkan pengendara sebagai tempat beristirahat sejenak, dengan demikian tata letak Monumen Perjuangan Masyarakat Cupak memberi dampak positif bagi lingkungan sekitar selain memperhitungkan nilai estetikanya juga kondisi daerah setempat.

Temuan pada tata letak Monumen Perjuangan Masyarakat Cupak berupa alasan didirikannya
Monumen di lokasi tersebut, ternyata setelah ditetili dan didukung oleh hasil wawancara dari masyarakat sekitar penempatan lokasi monumen sangat berpengaruh pada bentuk monumen hingga citra dari masyarakat sekitar. Monumen Perjuangan Masyarakat Cupak dibangun untuk mengingat dan mengenang sejarah, bahwa yang ikut dalam perperangan bukan hanya masyarakat dari daerah Cupak semata, tetapi juga dari daerah lain yang berdekatan dengan daerah Cupak seperti daerah Guguak, Pasar Usang, Talang, Koto Baru dan daerah lainnya. Alasan kuat didirikannya Monumen Perjuangan Masyarakat Cupak bukan karena perjuangan oleh masyarakat Cupak tetapi karena titik pusat perjuangan berada di daerah Cupak. Berkaitan dengan sebutan nama monumen bagi masyarakat Cupak dan sekitarnya, hanya menyebut Monumen Perjuangan Masyarakat Cupak dengan nama "Tugu Perjuangan", hal ini dikarenakan tidak ada nama monumen yang tertera di sekitar monumen. Setelah dilakukan wawancara dengan seniman yang bertugas membuat Monumen Perjuangan Masyarakat Cupak, diketahui bahwa alasan tidak diberikan nama pada monumen karena tidak adanya permintaan dari pihak pemerintah kabupaten, sedangkan Monumen Ayam Kukuak Lenggek yang berjarak sekitar kurang lebih $6 \mathrm{~km}$ dari Monumen Perjuangan Masyarakat Cupak yang juga dibuat oleh perupa yang sama (Asnam Rasyid dan Rajudin) memiliki nama serta keterangan yang disertai dengan tanda tangan seniman pembuatnya. Hal ini juga karena kurang perhatian pemerintah terhadap Monumen Perjuangan Masyarakat Cupak di Kabupaten Solok.

\section{KESIMPULAN DAN SARAN \\ 1.Kesimpulan}

Monumen Perjuangan Masyarakat Cupak dibuat berdasarkan cerita sejarah tentang sebuah perjuangan yang terjadi di daerah Cupak Kabupaten Solok dan sekitarnya. Peristiwa ini terjadi pada saat agresi Belanda ke II, untuk mengenang semangat tentara dan masyarakat dalam melawan penjajah. Bentuk monumen adalah merepresentasikan pejuang yang terlibat dalam merebut kembali kemerdekaan bangsa secara simbolik diwakili dengan tiga figur laki-laki dewasa dengan berpakaian berbeda. Perbedaan pakaian merepresentasikan latar belakang pejuang yang berbeda-beda.

Monumen ini memiliki fungsi ekspresi, sosial dan fungsi fisik. Fungsi ekspresi terdapat pada seniman atau perupa yang terlibat dalam pembuatan monumen. Fungsi sosial monumen yang ditempatkan di kawasan yang pertigaan jalan, sehingga mudah diakses dan 
dikunjungi sebagai destinasi wisata. Fungsi lain yaitu sebagai penada bagi orang yang melewati daerah Cupak, mereka dapat menandai monumen sebagai peta daerah Cupak (landmark).

Monumen Perjuangan Masyarakat Cupak tidak hanya sebagai pengingat perjuangan masyarakat Cupak saja, namun juga sebagai pengingat bagi masyarakat dari daerah lain seperti daerah Guguak, Talang, Pasar Usang Koto Baru dan daerah lain yang juga ikut berpartisipasi dalam perjuangan. Cupak hanya sebagai basis atau lokasi pertempuran, namun yang menyokong perjuangan didukung oleh masyarakat dari daerah sekitarnya.

\section{Saran}

Monumen Perjuangan Masyarakat Cupak saat ini terlihat tidak terawat dengan baik. Diharapkan kepada pemerintah daerah agar dapat mengalokasikan anggaran rutin untuk perawatan monumen. Pemerintah terkait juga harus memperhatikan keamanan dan kenyaman pengunjung dalam menikmati atau mengapresiasi monumen, untuk itu perlu merancang dan membangun kembali area monumen sehingga mampu memberikan keamanan dan kenyamanan bagi pengunjung maupun bagi pengguna jalan raya. Pada bagian atas monumen terlihat kabel listrik yang melintang dan merentang, sehingga sangat mengganggu dari segi estetika monumen. Pemerintah daerah dapat memperbaiki rentang kabel tersebut dengan cara mengalihkannya melalui jaringan bawah tanah.

\section{DAFTAR RUJUKAN}

Darsono, S. K. (2007). Estetika. Bandung: Rekayasa Sains.

Fieldman, E. B. (1991). Art As Image And Idea. Yogyakarta: Institut Seni Indonesia Yogyakarta.

Gustami, S. (1990). Art As Image And Idea (Terjemahan). Yogyakarta: Institut Seni Indonesia Yogyakarta.

Lexy J. Moleong. (2004). Metodologi Penelitian Kualitatif. Bandung: Remaja Rosdakarya.

Mikke Susanto. (2002). Diksi Rupa. Yogyakarta: DictiArt Laboratory.

Sahman, U. (1993). Mengenal Dunia Seni Rupa. Semarang: IKIP Semarang Press.

Sumardjo, J. (2000). Filsafat Seni. Bandung: Penerbit ITB.

Susanto, M. (2011). Diksi Rupa (1st ed.). Yogyakarta: DictiArt Lab.

Wucius Wong. (1989). Beberapa Asas Merancang Trimatra. Bandung: ITB. 